\title{
PENGEMBANGAN KONTEN PEMBELAJARAN IT PADA MASA COVID 19 BERBASIS TOTAL QUALITY MANAGEMENT
}

\author{
Ahmad Khoiron Minan ${ }^{1}$, Eka Nur Afifah ${ }^{2}$ \\ 1Prodi Magister Manajemen Pendidikan Islam, UIN Sunan Kalijaga,Yogyakarta \\ 2Prodi Pascasarjana Pendidikan Guru Madrasah Ibtidaiyah, UIN Sunan Ampel, Surabaya \\ *Corresponding Author Email: minansendang@gmail.com
}

\begin{abstract}
This study describes the development of IT learning contentbased on Total quality management carried out at Teladan Elementary School Yogyakarta. During the Covid 19 era, educational institutions were required to be able to maximize the IT learning process, with the aim that the material could be conveyed well, but in reality many educational institutions were unable to maximize IT technology in the learning process. Therefore it is necessary to have a good approach in the planning process of IT learning, one of which is the Total Quality Management. This research uses a descriptive qualitative approach to the type of case study. The results showed that SD Teladan Yogyakarta carried out several stages in the development of IT learning content based on Total quality management, these stages include determining standards (input), monitoring results and comparisons with standards (processes), improving dissemination (output) and new standard proposals. (outcome).
\end{abstract}

Keyword : Total quality management, IT Learning, Learning Content

\begin{abstract}
ABSTRAK
Penelitian ini memaparkan tetaang pengembangan konten pembelajaran IT berbasis Total quality management yang dilakukan di SD Teladan Yogyakarta. Pada masa Covid 19lembaga pendidikan dituntut untuk mampu memaksimalkan proses pembelajaran IT, dengan tujuan materi dapat tersampaikan dengan baik, akan tetapi pada kenyataannya banyak lembaga pendidikan yang tidak mampu dalam memaksimalkan teknologi IT dalam proses pembelajaran. Oleh sebab itu perlu adanya pendekatan yang baik dalam proses perencanaan pembelajaran IT, salah satunya adalah dengan Total Quality Management Penelitian ini menggunakan pendektakan kualitatif deskriptif dengan jenis studi kasus. Hasil penelitian menujukan bahwa SD Teladan Yogyakarta melakukan beberapa taha pan dalam pengembangan konten pemb elajaran IT yang berb aisis Total quality management, tahpan tersebut antara lain, penentuan standar (input), hasil monitoring dan perbandingan dengan standar (proses), perbaikan penyipangan (output) dan usulan standarbaru (outcome).
\end{abstract}

Kata Kunci: Total quality management, Pembelajaran IT, Konten Pembelajaran.

\section{PENDAHULUAN}

Era globalisasi adalah era dimana semua masyarakat diseluruh belahan bumi dapat dijangkau satu dengan yag lainnya atau terhubung dalam segala aspek kehidupan seperti politik, sosial budaya, ekonomi, pendidikan dan lingkungan (Hartini, 2015). Sebagai contoh adalah cepatnya sebuah informasi dapat tersampaikan antara satu individu dengan individu yang lain. Globalisasi telah sampai pada taraf menghilangkan sekatgeografis, administratif sosial dan budaya (Antariksa, 2017).

Globalisasi membuatperubahan yang sangatcepat dalam seluruh aspek kehidupan.Perubahan ini ditandai dengan berkembangan ilmu pengetahuan secara cepat dan canggih terutama dalam bidang

* Copyright (c) 2021 Ahmad Khoiron Minan dan Eka Nur Afifah

This work is licensed under a Creative Commons Attribution-ShareAlike 4.0 International License. 
informasi dan teknologi (Asmawi, 2018). Perkembangan teknologi daninformasi, harus diakui, berimbas secara langsung terhadap dunai pendidikan (Rahmah, 2018). oleh sebab itu dunia pendidikan harus mampu beradaptasi, dengan tujuan agar tidak tergerus dengan cepatnya perkembangan teknologi dan informasi, khususnya dalam metode dan proses pembelajaranyang dilakukan (Nuryatin, 2020).

Permasalah yang harus dihadapi saat ini selain dengan berkembangnya globalisasi adalah situasi kondisi yang terus berubah, seperti maraknya pandemi corona beberapa bulan ini yang mengakibatkan pembelajaran secara tatap muka ditiadakan dan diganti dengan pembelajaran berbasisi online, menyebabkan dunia pendidikan harus dipaksa untuk memaksimalkan potensi teknologi dan informasi yang ada (Kencanawaty et al., 2020). Adapun dalam prosespembelajaran kurang maksimal dikarenakan minat belajar siswa secara mandiri siswa belum terbentuk, sedangkan sebagian besar pembelajaran dengan berbasis online meniti bertakan kepada kesadaran siswa dalam belajar secara mandiri dimanapun dan kapanpun tanpa tanpa harus tersekat oleh ruang kelas (Sulistyawati, 2020). Permasalahan lain, banyak lembaga pendidikan yang tidak mampu memaksimalkan potensi teknologi dalam proses pembelajaran, berakibat pada tidak tersampaikannya materi pembelajaran dengan baik (Firman \& Rahayu, 2020).

Beberpa masalah yang telah dipaparkan oleh diatas harus secepatnya dicarikan solusi, salah satunya a dalah upaya untuk membuatsebuah trobosan baru dalam pengembangan konten pembelajaran IT, dengan harapan agar dalam pembelajaran yang dilakukan secara online mampu terlaksana secara maksimal. Pegembangan dalam hal ini bukan hanya dalam substansi materi akan tetapi perlu adanya pengembangan dalam hal materi buatan atau artificila materi, sehingga siswa tidak hanya berhenti pada inti darisebuah materitapi juga pengembangan materi yang didapatkan (Nugraha \&Winiarti, 2013).

Pengembangan konten pembelajaran dengan menggunakan ITmenjadi salah satu hal yang utama pada masa Covid 19, yang mana hampir seluruh lembaga pendidikan baik di tingkat dasar sampai pada tingkat perguruan tinggi menggunakan bantuan IT dalam proses pembelajarannya. Salah satu upaya yang ditempuh dalam rangka mengembangakan konten pembelajaran IT dengan menggunakan Total Quality Managemen (TQM), yang mana dalam konsep TQM adalah upaya perbaikan kulitas secara menyeluruh dan terus menerusserta berfokus pada kepuasan pelanggan yang dijadikan sebagai sasaran utama dalam proses impelementasinya dalam dunia pendidikan (Septiadi, 2019). Penerapan TQM dalam pengembangan dan perbaikan kulitas pendidikan telah terbukti dalam memberikan dampakyang besar dalam mencapaitujuan (Maryamah,2013).

Total quality management secara umum adalah aplikasi manajemen (perencanaan, pengorganisasian, pelaksanaan dan pengawasan) yang bertumpu pada pemenuhan kebutuhan pelanggan dan perbaikanyang dilakukan secaraberkesinambungan atau secara terusmenerus (Hazra et al., 2016). Jika Total quality management diterapkan dalam konteks pendidikan, maka Total quality management menjadi sebuah filosofi metodelogi tentang perbaikan secara terus menerus yang dapat memberikan seperangkatalat praktis kepada institusi pendidikan dalam memenuhi kebutuhan, keinginan dan harapan pelanggan pada saat ini maupun masayang akan datang (Indana,2017).

Pengembangan konten pembelajaran dengan menggunakan Total quality management memiliki beberapa syarat yang harus dipenuhi salah satunya adalah keterlibatan seluruh civitas akademik pembelajaran dalam pengembangan konten pembelajarn IT. Adapaun prinsip harus adala dalam pengembangan konten pembelajaran adalah keterlibatan secara total, fokus pada pelanggan, komitmen, pengukuran dan perbaikan yang dilakukan secara berkelanjutan (Indana, 2017).

Penelitian tentangpengembangan konten pembelajar an dalam hal ini masih sangat sulit ditemukan terutamayang berfokus pada ranah manajemen pengembangan atau pengelolaan konten pembelajaran. 
Kebanyakan penelitian (Astini, 2020; Kencanawaty et al., 2020; Lestari et al., 2020) lebih berfokus pada metode-metode penyampaian atau konten yang dibuat dengan teori-teori yang didapatkan, bukan pada ranah manajemen. Selain itu yang menjadi unik adalah konsep manajemen pengembangan konten pembelajaran dipadukan dengan Total quality management yang mana ini berfokus pada pelanggana dalam hal ini peserta didik. Pengololaan konten pembelajaran IT di SD Teladan menjadi bahasan yang menarik terutama pada masa pandemi Covid 19, yang mana dalam prosesnya melibatkan seluruh komponen yang adala dalam sekolah dari kepala sekolah, stafIT, pustakawan, pendidikdan peserta didik Konsep ini tentunya sejalan dengan prinsip Totalquality management, hasilakhirnya adalah SD Teladan mampu meningkatkan daya saingnya dimata para pelanggan.

\section{METODE PENELITIAN}

Metode yang dilakukan dalam penelitian adalah penelitian kulitatif deskriptif yang dengan jenis studi kasus. Penelitian ini berusaha untuk mendiskripsikan tentang proses pengembangan konten pembelajaran IT yang ada di SD Teladan Yogyakarta. Hal ini sesuai dengan pengertian dari penelitian kualitatif menurut Sugiyono yaitu menggambarkan kondisi obyek secara alamiah (Sugiyono, 2014). Dengan demikian, dalam penelitian kualitatif peneliti menjadi sumber instrument yaitu pengumpul data secara langsung. Penelitian ini bersifat deskripsi analisis, yang mana pengumpulan datanya dilakukan melalui; observasi, wawancara serta dokumentasi, kemudian peneliti melakukan analisis sampai penelitian dinyatakan selesai.

\section{HASIL DAN PEMBAHASAN}

\section{Hasil}

SD Teladan Yogyakarta berdiri pada tahun 2014,yang teletak disebalah barat kabupaten Sleman, tepatnya di Jl. Kabupaten, kecamatan Gamping. SD Teladan didirikan berangkat dari semangat dan kepercayaan untuk membangun sebuah lembaga pendidikan Islam yang modern, yaitu dengan menempatkan Al-Qur'an dan As Sunnah sebagai dasar dan acuan paling tinggi dari semua keahlian dan pengetahuan. Hal ini sesuai dengan visi Sekolah Teladan yaitu, menumbuhkembangkan generasi insan kamil yang berakhlaq, qur'ani, dan smart. Karaketistik model pembelajaranyangada diSD Teladan terbagi menjadi empatmodel

\section{Integrated "Thematic" Learning}

Pembelajaran dengan memadukan tema unutk mengaitkan beberapa mata pelajaran sehingga dapat memberikan pengalaman bermakna kepada peserta didik Dalam pembelajarannya TK KB SD TELADAN YOGYAKARTA mengintegrasikan aspek kauniyah atau semesta alam dengan Qur'aniyah yang diimplementasikan dalam kehidupansehari-hari.

\section{Peer Teaching Methode}

Metode pembelajaran yang memberdayakan kemampuan peserta didikyang memiliki daya serap yang tinggi, peserta didik tersebut mengajarkan materi atau latihan kepada teman -temannyayang belum paham. 


\section{Visual Learning Style (Technology Based Instruction)}

Kegiatan pembelajaran yang menggunakan konsep ICT sebagai media pembelajaran sehingga peserta didik mendapat pengalamanyang bersifat kongkret, menarikdanlebih menantang.

\section{Active and Fun Learning}

Kegiatan pembelajaran yang menekankan pada "Apa yang saya dengar, saya lupa, Apa yang saya dengar dan lihat, saya ingat sedikit. Apa yang saya dengan, lihat dan tanyakan atau diskusikan dengan beberapa teman lain, saya mulai paham. Apa yang saya dengar, lihat, diskusikan dan lakukan, saya memperoleh pengetahuan dan ketrampilan. Apayang saya ajarkan pada orang lain, saya kuasai.

\section{Prinsip Pelaksanaan TQM dalam lembaga pendidikan}

Pelaksanaan program dalam lembaga pendidikan, dapat dikatakan telah menerapkan KonsepTQM apabila telah menerapkan beberapa prinsip sebagai berikut :

1. Fokus pada pelanggan, prinsip dasar dalam pelaksanaanTQM adalah fokus pada pelanggan. Pelanggan dijadikan sebagai tolak ukur keberhasilan dalam pelaksaanaan prosespembelajaran. Pelanggan dalam lembaga pendidikan terdiri dari pelanggan interal (siswa, guru, staf dan dewan sekolah) dan pelanggan ekstenalterdiri dari (wali siswa, masyakat, dan organisasi diluar sekolah) (Indana,2017). Oleh sebab itu tujuan akhir dari TQM adalah kepuasan pelanggan.

2. Perbaikan berkelanjutan, proses yang dilakukan secara terus menerus dalam perbaikan kualitas dengan diubah, ditambah, dikembangkan dan dimurnikan (Pettalongi, 2010).

3. Ketelibatan total, dalam hal ini setiap kom ponen dimulai dari unsur pimpinan sampai dengan para staf harus secara aktif dalam mencapai tujuan yang telah ditetapkan oleh lembaga (Septiadi,2019).

4. Pengukuran, dalam pandangan mutu pendidikan lama mutu pendidikan dapat diukur dengan skor atau nilai yang didapatkan peserta didik, sedangkan dalam pandangan baru mutu dapat dilihat dari kemampuan dan kinerja lulusan dalam menjawab tuntutan pengguna (wali sisiwa dan masyakat) (Hartini, 2015).

\section{Discussion}

\section{Implementasi TQM dalam Pengembangan Pembelajaran IT}

Prose pembelajaran yang ada diSD Teladan secara umum melakukan menggunakan prinsip Total quality management, ini terbukti dengan adanya proses evaluasi secara terus menerus yang dilakukan oleh kepala sekolah berdasarakan masukan dari seluruh komponan sekolah. Dalam pengembangan konten pembelajaran IT SD Teladan melakukan beberapa manajemen perencaan yang sesuai dengan prinsip Totalqualitymanagement.

\section{Penetapan Standar,}

menurut (Sallis, 2010) penentuan standar mutu dilakukan sebagai usaha dalam penyelenggaraan pendidikan yang menerapkan prinsip penggunaan sumber daa yang efisien, penentuan standar mutu lebih dikenal dengan jaminan mutu (quality assurance). Jaminan mutu berupa kemampuan dasar yang hendak dicapai dalam proses pembelajaran atau materi pembelajaran pada masing-masing bidang pendidikan dan sesuai dengan jenjang pendidikan yang ditempuh.(Wiyani et al., 2016) Oleh sebab itu, 
sebelum melakukan pengembangan pembelajaran seorang pendidik harus menetapkan tujuan dan standaryang harus dicapai oleh peserta didiksetelah melakukan proses pembelajaran. Standar dalam hal ini adalah batas minimalyang harus dicapai peserta didik, setelah tersampaikannya materi pembelajaran. Sebelum melakukan upaya pembuatan konten pemebelajaran dengan IT di SD Teladan melakukan rapat pimpinan dan staf IT untuk membuat gambaran awal tentang konten pembelajar IT, dalam rapat ini pembahasan awal adalah mengani media penyampaikanyangakan diberikan apakah memalui Youtube, Web atau aplikasi. Setelah melakukan rapat terbatas dengan pimpinan dan staf IT, dilanjutkan dengan rapat terbuka yang dilakukan oleh seluruh staf pendidik, pustkawan dan seluruh yang terlibat dalam pembelajaran. Pada rapat ini membahas tentang standar yang akan dicapai peserta didik setelah mendapatkan materi berupa konten pembelajaran IT, selain itu dalam rapat ini ditentukan pembagian jadwal sesuai dengan telah ditentukan. Penentuan stadar ini menjadi sesuatuyang sangat penting sebagai goal yang akan dicapai dalam proses pembelajaran. Berangkat dari konsep diatas dalam menentukan standarawal dapat dilihat padagambar 1 :

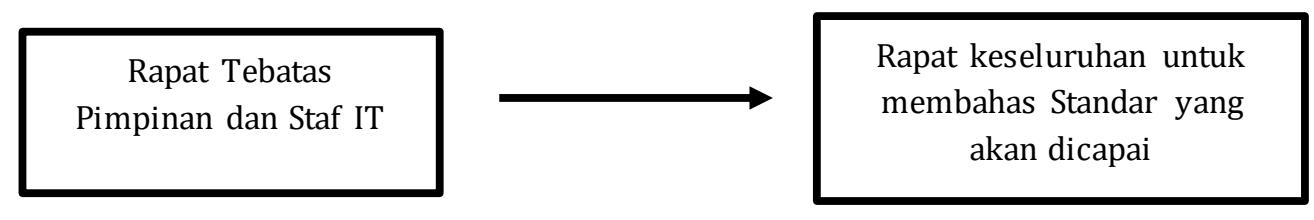

\section{Gambar 1. Penentuan standar yang akan dicapai dalam proses pembelajaran IT}

Pada tahapan ini prinsip Total quality management yang dilaksanakan adalah keterlibatan secara menyeluruh dalam menentukan standar yang ingin dicapai dalam proses pembelajaran, selian itu dalam perencanaan juga dibahas berkenaan dengan media penyampaian pembelajaran, sesuai dengan kesanggupan dan komitmen seluruh pihak yang terlibat dalam proses pembelajaran yang menerapkan pinsip fokus pada pelanggan.

2. Hasil monitoring dan perbandingan dengan standar

Setelah menetapkan standar, maka proses selanjutnya adalah pelaksaan pembelajaran yang diikuti dengan hasil evaluasiatau monitoring pembelajaran, evaluasi yang dimaksud adalah perbandingan proses pembelajaran dengan standar yang telah ditetapkan.(Septiadi, 2019) Pada tahapan ini kepala sekolah Staf IT selaku penanggung jawab proses pembelajaran IT melakukan evaluasi kinerja dari para pendidik yang dilakukan selama rentang waktu 1 minggu sekali untuk proses evalusi mingguan yang dilakukan melalui media Whastapp, dan proses evaluasi yang dilakukan secara besar dengan tatap muka yang dilakukan selama 1 bulan sekali, pada evaluasi bulanan pihak sekolahjuga menampug aspirasi dari wali murid atau peserta didik tentang proses pembelajaran yang telah dilakukan, selain itu juga menampung evaluasi dari segala yang terlibat dalam proses pembelajaran. Selain itu untuk mengukur seberapa efektifnya proses pembelajaran guru memberikan tugas bulana kepada siswa, berkenaan dengan materi yang telah disampaikan selama 1 bulan, hasil dari tugas tersebut disampaikan pada rapat bulanan sebagai evaluasi. Evaluasi bulanan dilakukan sebagai bentuk monitoring bulanayang dilakukan oleh pimpinan, dan mengukur sebarapa efektif dan efisinenya pembelajaran yang telah dilakukan. Pada tahapan ini prinsip Total quality management adalah pengkuran, fokus pada pelanggan dan keterlibatan secara menyeluruh. Halinitelah diungkap padagambar 2. 


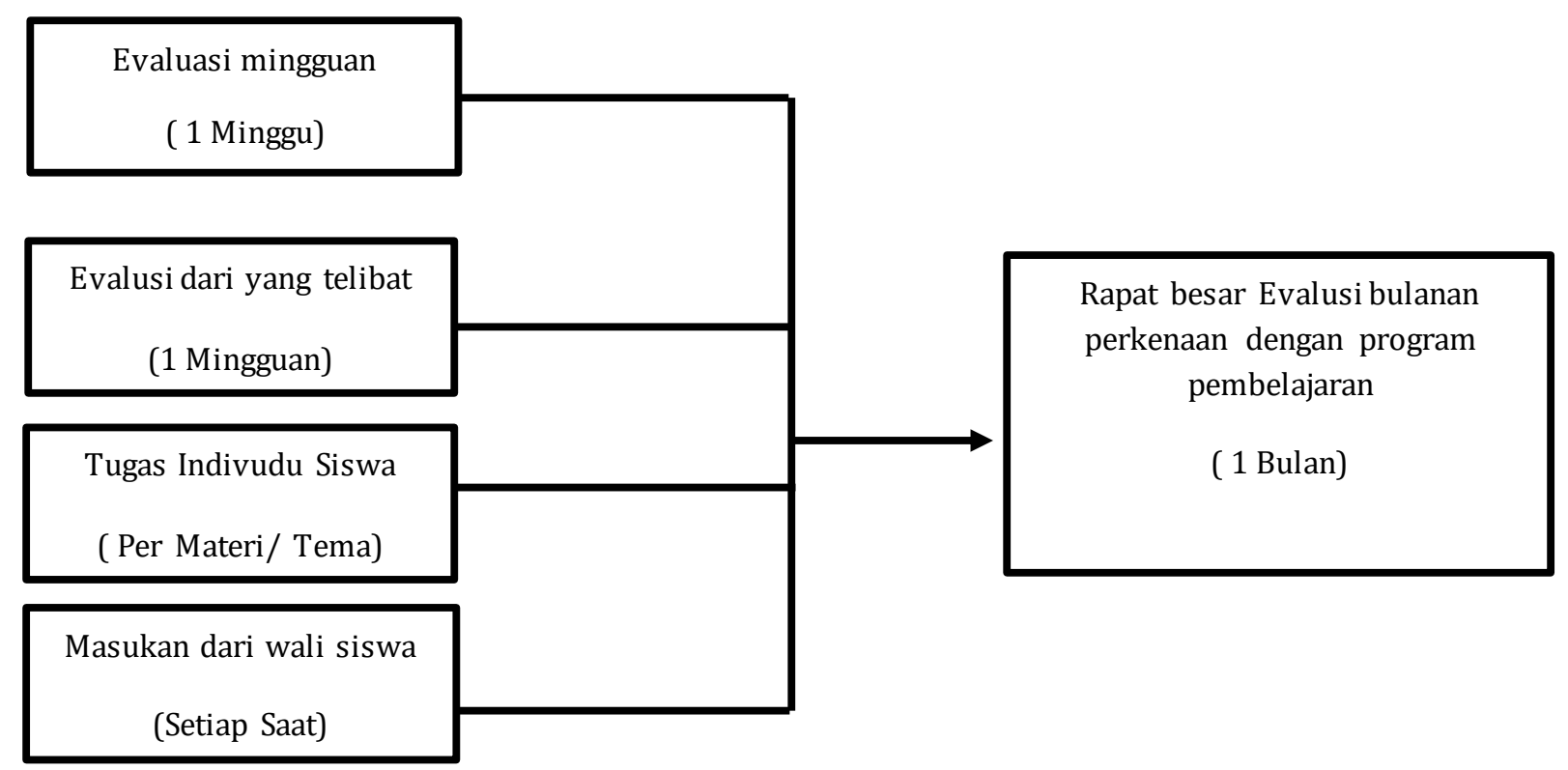

\section{Gambar 2. Proses Monitoring SD Teladan Yogyakarta}

\section{Perbaikan penyimpangan}

Setelah mendapatkan gambaran mengenai hasil monitoring, maka tugas pendidik adalah perbaikan dari hasil monitoring pembelajaran yang tidak sesuai dengan standar yang telah ditentukan.(Maghfiroh, 2018) SD Teladan melalukan perbaikan setelah adanya evaluasi yang telah dilakukan selama 1 bulan sebelumnya mulai dari perbaikan konten meliputi suara, gambar, metode penyampaian dan contoh-contoh materi yang mudah dipahami oleh peserta didik dan yang relevan dengan keadaan yang ada, pada tahapan ini prinsip Total quality management yang dilakukan adalah perbaikan. Pada tahapan ini seluruh yang terlibat dalam proses pembelajaran melakukan perbaikan secara menyeluruh terhadap standar-standar awal yang ditentukan. Pada proses ini termasuk dalam prinsip pengukuran.

4. Usulan standar baru,

Dari hasil perbaikan dari penyimpangan maka hasil akhirnya adalah usulan standar baru dan menjadi standar yang akan diterapkan pada konten pembelajaran selanjutnya, maka konsep TQM berfokus pada perbaikan berkelanjutan dengan adanya standar baru yang akan ditetapakan pada setiap sikulis. Pada tahapan selanjutnya setelah melakukan perbaikan adalah usulan standar baru. Para staf guru, kepala sekolah dan staf IT melakukan evaluasi dan penetapan standar baru. Pada tahapan ini evaluasi dijadikan sebagai usulan standar baru yangakan ditepakan. Siklus yang dilakukan adalah siklus dua bulan yang dari penetapan standar sampai pada baru. Pada proses ini menerapkan prinsip perbaikan secara terus menerus.

Pendekatan manajemen mutu dalam proses pengembangan konten pembalajaran IT harus dilakukan secara menyeluruh mulai dari input, proses, output, dan outcome (Indana,2017), sehigga dari penyataan diatas dapat dikatakan bahwa hasil total quality management dapat diukur melalui input, proses, output dan outcome. Input dinyatakan bermutu apabila kurikulum atau tagret yang ditetapkan jelas dan terarah. Proses dianyatakan bermutuapabila dalam konten pembelajara dapat dilakukan dengan menyenangkan, aktif, keratif dan dapatsesuai dengan perencaan yangtelah ditetapkan. (Rahmah, 2018) Output dinyatakan bermutu apabila telah memenuhi kriteria yang ditetapkan dengan tatap 


\section{Khazanah Pendidikan Islam, Vol. 3 No. 1: 21 - 29}

Pengembangan Konten Pembelajaran IT pada Masa Covid 19 Berbasis Total Quality Management Ahmad Khoiron Minan dan Eka Nur Afifah

memperhatakan berbaikan. Outcome dinyatakan bermutu apabila terdapat trobosan atau inovasi baru dalam setiap siklusnya. Berdasarkan tolakukur diatasmaka, proses pengembangan konten pembelajaran IT di SD Teladan dapatdijelaskan dalam tabel 1.

Tabel 1. Pengembangan konten pembelajaran IT berbasis TQM di SD Teladan Yogyakarta

\begin{tabular}{|c|c|}
\hline Unsur & Keterangan \\
\hline Penetapan Standar (Input) & $\begin{array}{l}\text { Pengebangan konten pembelajaran di SD Teladan meliputi, } \\
\text { Pentapan standar awal berupa analisa kebutuhan materi yang } \\
\text { akan disampaikan dan goal yang akan dicapai sesuai dengan } \\
\text { rencana pembelajaran }\end{array}$ \\
\hline $\begin{array}{l}\text { Hasil monitoring dan perbandingan dengan } \\
\text { standar (Proses) }\end{array}$ & $\begin{array}{l}\text { Evaluasi yang dilakukan selama seminggu sekali, masukan dari } \\
\text { wali siswa, masukan beberapa staf yang terlibat dan hasil } \\
\text { ulangan yang telah diberikan oleh pendidik kepada peserta didik. } \\
\text { Hasil evaluasi tahap awal adalah } \\
\text { 1. Penentuan jadwal uploading konten yang awalnya } 1 \\
\text { 2. Kunggu sebelum materi, terkadang molor. }\end{array}$ \\
\hline Perbaikan Peyimpangan (Output) & $\begin{array}{l}\text { Hasil yang diperoleh dari monitorong yang dilakukan adalah } \\
\text { bentuk konten pembelajarn IT sudah tergolong baik, akan tetapi } \\
\text { perlu adanya perbaikan dalam segi penyampaian materi dan } \\
\text { viariasi penyampaian, tidak hanya dilakukan melalui video akan } \\
\text { tetapi bisa melalui aplikasi pembelajara seperti Adobe Flas } \\
\text { Player }\end{array}$ \\
\hline Standar Baru (Outcome) & $\begin{array}{l}\text { a. Kepala sekolah sebagai penanggung jawab menentukan } \\
\text { standar baru sesuai dengan masukan yang ada. } \\
\text { b. Pendidik memberikan variasi penyampaian materi } \\
\text { kepada peserta didik } \\
\text { c. Sekolah mendengarkan evaluasi dari seluruh } \\
\text { komponan yang terlibat dalam proses pembelajaran. } \\
\text { d. Analisa kebutuhan baru sesuai dengan per baikan dari } \\
\text { penyimpangan. }\end{array}$ \\
\hline
\end{tabular}

Sumber : Di olah Peneliti ( 2020) 

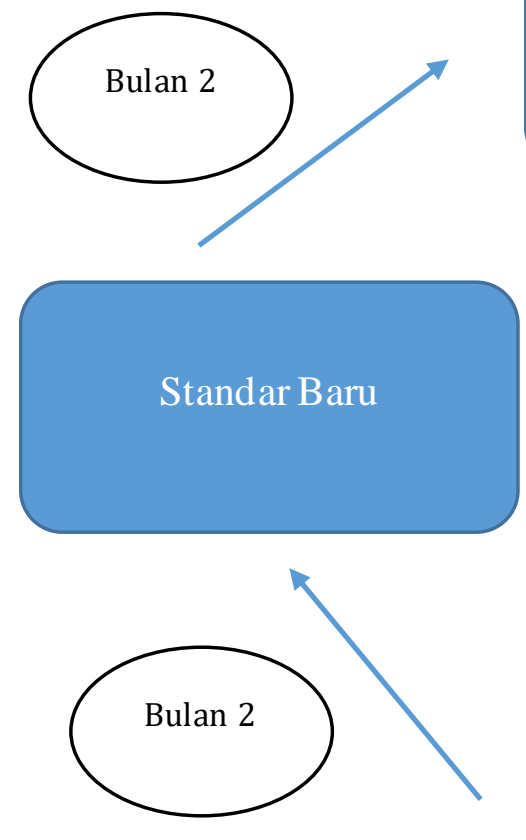

Penetapan Standar

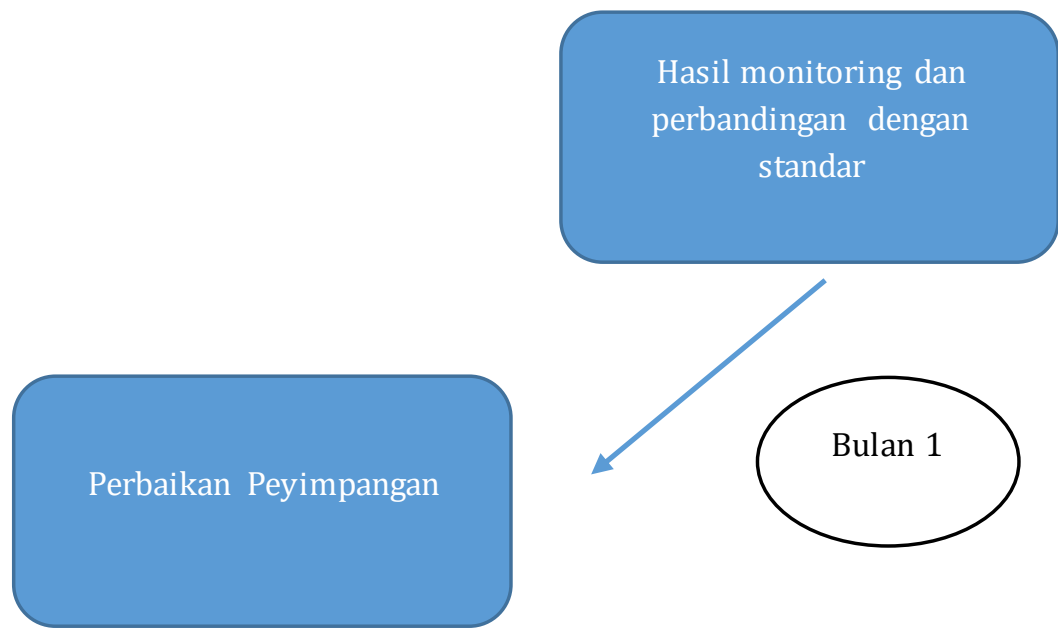

Gambar 3. Siklus Pengembangan Konten Pembelajaran di SD Teladan Yogyakarta

Berdasarkan penjelasan tabel 2 dangambar 3, dapat diketahui bahwa; pengembangan konten pembelajaran IT yang ada di SD Teladan Yogyakarta bertujuan untuk mencapai kepuasan pelanggan, dalam hal ini adalah peserta didik dan wali siswa, selain itu juga bertujuan untuk memaksimalkan pembelajaran ditengah pandemi Covid 19. Sala satu caranya adalah dengan menggunakan prinsip Total quality management, yang mana dalam prinsip ini bercirikan berfokus pada pelanggan, perbaikan secara berkelanjutan dan terus menerus, keterlibatan secara menyeluruh yang dilakukan oleh seluruh seluruh yang telilbat dalam proses pengembangan konten pembelajaran serta adanya pengukuran yang dilakukan dengan meilihat sebara efektif konten pembelajaran IT yang diberikan.

\section{SIMPULAN}

Prinsip yang harus dipengang dalam pengembangan konten pembelajaran IT berbasis Total quality management adalah adanya perbaikan secara terus menerus yang fokusnya adalah pada pelangan, jika ditinjau dalam konteks konten pembelajaran pelanggan merupakan pseserta didik. Perbaikan secara berkelanjutan itu dilakukan secara terus menerus, dilakukan dengan penuh komitmen, keterlibatan seluruh komponan dan pengukuran terhadap apa yang telah dikerjakan. SD Teladan Yogyakarta menjadi salah satu sekolah yang dalam pelkasanaan pengembangan konten pembelajaran IT menggunakan prinsip Total quality management dalam pelaksanaannya. Ini dilakukan sebagai langkah pelayanan kepada pelanggan yang terpaksa melakukan kegiatan pembelajaran di rumah dikarenakan pandemi Covid 19. Konsep yang diterapkan dalam pengengembangnnya adalah perbaikan secara terus menerus dengan penentuan standar awal dan berakhir pada penentuan standar baru. 


\section{DAFTAR PUSTAKA}

Antariksa, W. F. (2017). Analisis Manajemen Sumber Daya Manusia di Sekolah Dasar Islam Terpadu. Madrasah, 10(1), 47. https://doi.org/10.18860/madrasah.v10i1.5096

Asmawi, M. N. (2018). Kebijakan Pendidikan Islam Pada Era Globalisasi Pasar Bebas dan Revolusi Industri 4.0. Scolae: Journal of Pedagogy, 1(2), 101-109.

Astini, N. K. S. (2020). Pemanfaatan teknologi informasi dalam pembelajaran tingkat sekolah dasar pada masa pandemi covid-19. Lampuhyang, 11(2), 13-25.

Firman, F., \& Rahayu, S. (2020). Pembelajaran Online di Tengah Pandemi Covid-19. Indonesian Journal of Educational Science (IJES), 2(2), 81-89. https://doi.org/10.31605/ijes.v2i2.659

Hartini, K. (2015). Penerapan Total Quality Manajement (TQM) dalam Perguruan Tinggi. Al-Intaj: Jurnal Ekonomi Dan Perbankan Syariah, 1(1). https://doi.org/10.29300/AIJ.V1I1.766

Hazra, R., Irwansyah, M. R., \& Ikhtiarini, N. (2016). Implementasi Total Quality Management (TQM) dalam Meningkatkan Kualitas Output Madrasah Tsanawiyah (MTS) Negeri Seririt Kecamatan Seririt, Kabupaten Buleleng Tahun Pelajaran 2015/2016. Ekuitas: Jurnal Pendidikan Ekonomi, 4(2). https://doi.org/10.23887/ekuitas.v4i2.12791

Indana, N. (2017). Implementasi Total Quality Management (TQM) Dalam Meningkatkan Mutu Pendidikan (Studi Kasus di MTs Salafiyah Syafi'iyah Tebuireng). Al-Idarah, 1(1), 62-86.

Kencanawaty, G., Febriyanti, C., \& ... (2020). Tantangan dan Strategi Pembelajaran Matematika di Masa Adaptasi Kebiasaan Baru (AKB) Dampak dari Covid-19. Diskusi Panel Nasional ..., 58, 215-220.

Lestari, W., Pratama, L. D., \& Hidayatillah, W. (2020). Persepsi Guru dan Siswa Tentang Penggunaan Media Edutainment di Tengah Pandemi Covid-19. Jurnal Pendidikan Matematika RAFA, $6(2), 109-122$.

Maghfiroh, L. (2018). Strategi Peningkatan Mutu Pendidikan Madrasah melalui Total Quality Management (TQM) di Madrasah Ibtidaiyah Wahid Hasyim Yogyakarta. TA'LIM : Jurnal Studi Pendidikan Islam, 1(1), 19-39. https://doi.org/10.29062/TA'LIM.V1I1.623

Maryamah. (2013). Total Quality Management (TQM) dalam Konteks Pendidikan. Ta'dib, 18(1), 812.https://doi.org/10.5958/2348-7534.2014.01294.x

Nugraha, D., \& Winiarti, S. (2013). Pengembangan Media Pembelajaran Sistem Pelacakan Pada Mata Kuliah Kecerdasan Buatan Berbasis Multimedia. Jurnal Informatika, 2(1), 738-748. https://doi.org/10.12928/jstie.v2i1.2604

Nuryatin, S. (2020). Adaptasi Metode Pembelajaran Melalui E-Learnig Untuk Menghadapi Era New Normal.Akrab Juara, 5(1), 43-54.

Pettalongi, S. S. (2010). Konsep Total Quality Management dalam Pengembangan Kurikulum. Jurnal Hunafa, 7(1), 37-36.

Rahmah, U. (2018). The Implementasi Total Quality Management (TQM) di SD Al-Hikmah Surabaya. MANAGERIA: Jurnal Manajemen Pendidikan Islam, 3(1), 111-131. https://doi.org/10.14421/manageria.2018.31-06

Sallis, E. (2010). Total Quality Management in Education (Fahrurrozi \& A. A. Riyadi (eds.)). IRCiSoD. Septiadi, W. (2019). Tinjauan Total Quality Management (TQM) Pada Lembaga Pendidikan Islam. Nidhomul Haq: Jurnal Manajemen Pendidikan Islam, 4(1), 34-51. https://doi.org/10.31538/ndh.v4i1.105

Sugiyono. (2014). Cara Mudah Menyusun, Skripsi, Tesis, dan Disertasi. Alfabeta.

Sulistyawati, T. E. (2020). Perspektif Aksiologi Terhadap Penurunan Minat Belajar Anak di Masa Pandemi. 1(1), 33-43.

Wiyani, N. A., Najib, M., \& Sholichin, S. (2016). Penerapan TQM dalam Pendidikan Akhlaq. Jurnal Pendidikan Islam, 28(2), 221. https://doi.org/10.15575/jpi.v28i2.545 